\title{
АВТОРСКАЯ МАСКА
}

\author{
А.А. Разин
}

\section{УЧИТЬСЯ НА ПОЛОЖИТЕЛЬНЫХ ПРИМЕРАХ И ЧУЖИХ ОШИБКАХ}

Аннотация. Выдаюшиеся люди наряду с плодотворной деятельностью нередко совершают непростительнье ошибки, которые приводят к трагическому кониу. Известные личности нередко страдают от дефицита любви или оказываются жертвой погони за славой. Автор размылляет по поводу взаимообусловленности соииокультурной среды и качеств личности, отмечает изъяны цฺивилизации, акцентирует внимание читателя на проблеме сохранения этнокультуры и нелинейного мышления.

Ключевые слова: филология, любовь, суицид, слава, линейное мышиение, нелинейное мышление, диалектика, этнокультура, одиночество, индивидуализм.

प еловековедение, в том числе литературоведение, не может обойтись без анализа примеров жизни и деятельности известных людей, особенно художников (писателей, поэтов, живописцев...). Пусть их опыт послужит на пользу следующим поколениям.

В процессе анализа я придерживаюсь следующей исходной позиции: наша прозападная цивилизация не знает и не использует закономерности становления человека. Она многое даёт для развития способностей, но далеко не все условия предоставляет для становления целостного (гармоничного) человека, и обретения им разума как высшего уровня сознания, основанного на нелинейном (многомерном) мышлении. Разумеется, индивид, не овладевший нелинейным мышлением, плохо ориентируется в жизненном пространстве, не находит пути восхождения к своей истинной природе. Ему говорят: «Ты волен делать свою судьбу». И он верит, что, действительно, в его силах осуществить мечту. Но ему невдомёк, что, не владея соответствующей социальной технологией, положительного результата достичь невозможно.

По моему убеждению, главные недостатки западной цивилизации заключаются в следующем:

- Для общественных отношений характерно отчуждение - в отношениях между людьми ощущается дефицит любви (в сущности, она лишь декларируется).

- Ребёнок в своём развитии ограничен уровнем знаний и линейным (одномерным, формально-логическим) мышлением, и неудивительно, что часто совершает неразумные поступки.
- Индивид не включён в сложные социальные связи (соответствующие человеческой природе), и обречён на одиночество или примитивную жизнь.

\section{А.С. Пушкин}

Едва ли кого-то из россиян оставляет равнодушным личность и трагическая смерть А.С. Пушкина. К их числу отношусь и я. Рассматривая биографию великого поэта, пытаюсь акцентировать внимание на трагизме его жизни и факторах, обусловивших его обречённость.

Кто главный виновник в преждевременной смерти А.С. Пушкина? Как это ни странно, но главными виновниками были родители, лишившие его внимания, особенно мать, обделившая его лаской. Она проигнорировала первую закономерность становления целостного человека - окружить ребёнка безмерной любовью. К сожалению, высший свет никак не помог пробудить её материнский инстинкт - она жила развлечениями, балами, сплетнями. А впечатлительный сын Саша очень нуждался в материнском воркующем голосе, ласковом прикосновении самого близкого, самого родного человека. Без ласки не укрепляется психика ребёнка. Из него вырастает неуверенный в себе мужчина, подверженный сомнениям, психической рефлексии. Именно по причине дефицита материнской ласки у будущего поэта развилась психическая рефлексия. В 14 лет он изучал своё лицо и нашёл его ужасным, и в стихотворении на французском языке назвал себя «маленькой обезьянкой». Если ребёнок ощущает себя 


\section{Авторская маска}

ущербным, это - аномалия, а если ощущает себя любимым - считает себя неотразимым, имея любые физические недуги: будучи хромым, кривым или безобразным подобно Квазимодо.

По причине комплекса неполноценности Пушкин был задиристым, участвовал в более чем десяти дуэлях. В Царскосельском лицее стрелялся даже со своим другом Кюхельбекером («Кюхлей», как он его прозвал). Можно предположить, что донжуанский список Пушкина тоже был следствием комплекса неполноценности, то есть своеобразной формой самоутверждения - душевно здоровый человек не мог хвастаться «победами» над женщинами, не мог говорить, что Натали является его сто тринадцатой женщиной. Думается, что по этой же причине написал: «Чем меньше женщину мы любим, тем легче нравимся мы ей». (А может, считал их пустышками, поэтому относился к ним потребительски.) К жене, правда, относился как настоящий джентльмен и никогда ей не изменял.

Главное позитивное влияние на Пушкина оказала крепостная крестьянка, няня Арина Родионовна, наделённая бесконечной добротой и душевностью. Она же пробудила в нём гениальность, приобщив его к фольклору, народной мудрости. Но маму никто не заменит - только она обладает всесильным инструментом, называемым материнское сердце.

Вторым виновником, выведшим Пушкина из душевного равновесия, была собственная жена. Наталья Гончарова была никчёмной подругой Пушкина. Литература её не занимала, жила только балами, не была способна понимать его, поскольку жила в другом измерении - не поднялась выше уровня ощущений, эмоций, чувств и инстинктов, страстно любить была способна только свою красоту. Мужа любила потребительски - любила постольку, поскольку он обожал и боготворил её, ценила его за известность, страстность, пылкую любовь, нежность, ласку, снисходительное отношение к инфантильности жены и понимание её души (по-детски наивной и доверчивой), потакание её прихотям, умение обхаживать, восхищаться и выражать чувства: «моя Мадонна», «чистейшей прелести чистейший образец».

Наталья, тем не менее, заслужила почитания со стороны Пушкина. Он, добившись долгожданной помолвки с невестой, в период Болдинской осени написал 5 повестей, «Маленькие трагедии», 30 стихотворений, 2 главы «Евгения Онегина». Его любовь выразилась в том, что он впоследствии окружил жену вниманием, упреждал её желания, создал комфортные условия: снял квартиру в центре Петербурга, завёл прислугу. Но Наталья не могла ответить полноценной любовью, кроме любви мужа ей нужно было поклонение толпы — основную жизненную энергию она получала от признаний в любви. Ей был составлен список поклонников, в котором числилась почти сотня имён, среди них оказался и император Николай I. К чести Натальи, она, ничего не тая, рассказывала мужу о признаниях ловеласов. Это была их тайна. Пушкин говорил ей: «Семья без тайны - это не семья». Но ей было невдомёк, что на самом деле эта тайна была ядом для сердца Пушкина. Его угнетало осознание, что жена была бездуховной и неспособной полноценно любить (так, как он сам любил). Ему оставалось лишь добиваться, чтобы она, хотя бы физически, не изменяла, делал нарекание: не давай повода для ревности.

На каждом балу несколько человек говорили о своей влюблённости. Наиболее настойчивым и бесцеремонным был Дантес. Когда Пушкин запретил пускать его в дом, Дантес женился на сестре Натальи Екатерине и снова стал иметь возможность встречаться с Натальей на правах родственника. Пушкин запрещал жене танцевать с Дантесом, та обещала, но на следующем балу первый тур вальса кружила с ним. В присутствии ловеласа Дантеса она не владела собой. Тот отчиму с радостью писал: «Наталья увлечена мной». Наталья, к её чести, высказывала своё тревожное состояние, боялась за себя, боялась сорваться, предчувствовала приближение трагедии. Наблюдательный Пушкин и сам всё замечал, но не знал что предпринять, а жену успокаивал: «Не тревожься, я всё знаю, всё будет хорошо». Он всегда относился к ней по-рыцарски, как к своей половинке. Будучи смертельно раненым, жалел жену, старался утешить её: «Как тяжело будет тебе — моей смерти не простят, лучше уезжай из столицы - здесь будет невыносимо. Но знай: ты ни в чём не виновата». Этим самым он доказал способность полноценно любить.

Беда поэта заключалась в эстетизме - превыше всего ставил красоту. Видимо, оттого, что не встретил женщину, подобную Татьяне Лариной. Несмотря на свою гениальность, Пушкин был дитём своего времени: себя называл «потомок негров безобразный» и считал брак с первой красавицей России неравным. Но он был неправ. В народе говорят: мужчина должен быть чуть красивее обезьяны. Действительно, Пушкина женщины любили. За что? За большие голубые глаза, вьющиеся каштановые волосы, эмоциональность, обаяние, остроумие, неукротимый характер. Тем не менее, известный во всей России поэт ощущал себя одиноким, М.Ю. Лермонтов не случайно писал: «Один, как прежде...». Рядом с Пушкиным не оказалось друга, способного заменить Арину Родионовну. Почему? Потому что высший свет состоял из индивидуалистов, занятых своими проблемами и стремлением чем-нибудь удивить мир или сломать «Я» в другом человеке, особенно «восставшем против мнений света». 


\section{Филология: научные исследования 4 (08) • 2012}

Император Николай I (прозванный в народе «Палкиным») тоже был заинтересован в гибели поэта: с одной стороны, Пушкин был неудобен для него как свободомыслящий человек и критиковавший самодержавие и чиновников, а с другой - мешал как муж красавицы, в любви к которой он признавался на балу и во время свидания. Да, Наталья была с ним на свидании, но она не допустила физической близости. Царь оказался в недоумении - кроме как от неё ни от кого не получал отпора - любая женщина почитала за честь оказаться в одной постели с царём. Отказ Натальи он, надо полагать, воспринял как оскорбление своей высокой особы, и Пушкину как сопернику не простил своего поражения в заочной дуэли. После смерти Пушкина он молодой вдове назначил высокую пенсию, погасил все её долги и на правах благотворителя и самодержца имел доступ к ней. И лишь через четыре года выдал её за генерала П.П. Ланского.

Пушкин был уверен, что убьёт Дантеса, потому что стрелял без промаха. Зная свой вспыльчивый характер и честолюбие, он постоянно упражнялся в стрельбе, а чтобы рука была твердая, ходил с металлической тростью весом полпуда. Даже будучи смертельно раненым, попал точно в цель. Конечно же, ему не стоило стреляться со своим соперником. Не надо было подбирать брошенную перчатку, не действовать по навязываемому врагами правилу, а быть философом и в практической жизни и иметь мужество жить согласно своему философскому миропониманию. Написал же гениальные слова: «Хвалу и клевету приемли равнодушно, и не оспоривай глупца». Написать написал, но почему сам не руководствовался ими в жизни? Почему пошёл на поводу «мнений света»? Налицо разрыв между словом и поступком. По какой причине? Не взошёл до уровня разума (мудрости) или идентифицировал себя с теми, кто клеветал на него, и боялся в их глазах выглядеть трусом? В любом случае нет оправдания прогнившему высшему свету. Моё убеждение: тот, кто называет дворянство генофондом русской нации, плохо занимался этническим самопознанием и не знает, что такое русский народ!

Хорошо ещё, что Пушкин никого не убил, иначе Россия лишилась бы бренда - убийца не мог бы стать предметом национальной гордости. Имя поэта было спасено благодаря хитрости его заклятого врага: Дантес выстрелил раньше (и выстрелил подло в живот), не доходя до барьера, а грудь самого Дантеса предусмотрительно была защищена стальным листом. Последний факт был установлен с помощью эксперимента постфактум.

Идя на дуэль, Пушкин был обречён: в тот период дуэль была запрещена, участников казнили. В случае если бы Пушкин убил Дантеса, его ожидал позорный конец - обязательно повесили бы. Суд, действительно, приговорил дуэлянтов Пушкина и Дантеса к смертной казни, но вмешался император - отправил Дантеса во Францию, тем самым выразил свою благодарность за убийство поэта.

Франция встретила убийцу как героя. Благодаря убийству российского гения, Дантес сделал политическую карьеру - стал сенатором. Какой вывод следует из такого факта? Если француз рассматривает вмешательство в чужие семейные отношения и дуэль как нормальное явление, если его не возмущает убийство гениального поэта, то напрашивается вывод: уровень духовности данного (хвалёного) общества невысокий.

Николай I боялся даже мёртвого Пушкина. Чтобы избежать народного волнения, гроб с его телом тайно вывезли из Петербурга ночью и похоронили рядом с церковью Святогорского монастыря на территории Михайловского имения.

Пушкин недожил своё, не воспитал своих наследников и наследниц, не претворил в жизнь творческие замыслы, недолюбил свою красавицу-жену. Что, кроме минусов, дала смертельная дуэль? Лишь радость врагам. Таков результат отсутствия философской рефлексии. И виноват в этом только сам поэт?

\section{М.Ю. Лермонтов}

Преждевременная смерть Михаила Лермонтова тоже стала огромной потерей для российской литературы, он создал бы ещё много психологически оправданных и философски продуманных произведений. Нет, думаю, он бы не затмил Пушкина, скорее дополнил бы его. Лермонтов по умонастроению был несколько иной: ближе к народу, ближе к униженным и обиженным, более критично относился к помещичьему строю и политике царского правительства, поэтому несколько иначе оценивал крестьянское восстание под предводительством Емельяна Пугачёва. А отрицательное отношение к опричнине Ивана Грозного выразилось в «Песне про царя Ивана Васильевича, молодого опричника и удалого купца Калашникова».

М.Ю. Лермонтов рос сиротой, воспитывался бабушкой Елизаветой Алексеевной Арсеньевой. Неустойчивость его психики, как и в случае с Пушкиным, в первую очередь можно объяснить именно отсутствием материнской ласки. Ему всегда не хватало душевного тепла, очень нуждался в любви, надеялся на её чудодейственную силу. Поэтому так много писал о ней. Но именно любимая женщина нанесла ему предательский удар. Ей оказалась Наталья Фёдоровна Иванова (в замужестве Обрескова), чувства к которой выразил в тридцати посвящениях. Но та предпочтение отдала мошеннику, укравшему драгоценности у своей тёти, 


\section{Авторская маска}

и за это разжалованному в рядовые. Можно предположить, что духовный мир Ивановой тоже был близок к уровню позорного избранника её. Конечно же, она не была достойна Лермонтова, и не стоило сожалеть о ней: достойный человек не нанес бы ему глубокую душевную рану — неслучайно он вопрошал: как жить дальше, если ангел изменяет?

Разочарован был Лермонтов не только в Ивановой, но и в высшем свете. В стихотворении «Смерть поэта» открытым текстом говорит о своём презрении к нему: «Вы, жадною толпою стоящие у трона, Свободы, Гения и Славы палачи!». «И вы не смоете всей вашей чёрной кровью поэта праведную кровь». Думаю, предвидел, что за такие слова будет наказан, но не мог кривить душой, не мог не выразить своего протеста, гнева, наблюдая разнузданную травлю поэта. Стихотворение написал, не подбирая дипломатических выражений, даже у Пушкина ни в одном произведении нет подобного вызова высшим кругам общества. Можно вообразить, как стали относиться к нему приближённые Николая I и привилегированные слои, демонстрирующие своё верноподданническое отношение к самодержцу. Можно предполагать, какое моральное давление стало оказываться на него, особенно после ареста за стихи. Ссылка на Кавказскую войну - это способ доказать человеку, что он никто. Психика не каждого человека может выдержать такое, особенно если душа поэтическая.

Хочу сказать, что трагическая смерть Лермонтова не была случайной - была уготована несовершенным социумом, в котором талантливые и свободолюбивые люди оказываются не в цене. Почему он своего товарища Мартынова называл «мартышкой»? Вовсе не потому, что презирал его - ему казалось, что он шутит. Просто-напросто человек, выведенный из душевного равновесия, как правило, ведёт себя неадекватно, шутит неудачно. Будь он носителем традиционной русской культуры, был бы свободен от психической рефлексии и обязательно извинился бы перед товарищем, инцидент был бы исчерпан. Человек неглупый, но почему не подумал о последствиях дуэли? Не хватило мужества отказаться? Скажем: погиб бы Мартынов - кому от этого стало бы лучше? Лермонтову? Конечно, нет - ему не нужна была смерть товарища. Одним словом, как и другие западники, был далек от философской рефлексии и стереотипно следовал ценностям западной культуры. И - напрасно.

\section{В.В. Маяковский, Ван Гог и Э. Хемингуэй}

Известно, что жизнь этих трёх личностей закончилась трагично - самоубийством. Самоубийство - это протест против несправедливости. Но каков механизм появления вызова окружающему миру? Что случилось с моим любимым поэтом Владимиром Маяковским? Как мог добровольно уйти из жизни человек с сильным духом, как ледокол, торивший путь товарищам по цеху, человек, презиравший корысть и быт, посвятивший себя служению людям, идее строительства новой жизни? Эта незаурядная натура всегда будет привлекать внимание читателей и исследователей. Я тоже вознамерился внести свою лепту: на примере подобной жизни надо учиться другим. Хочется исследовать эту тему.

Мне импонирует, что Маяковский утверждал идеи гуманизма, прославлял людей труда. Рад, что его жизненные установки были верными, не будучи членом коммунистической партии, служил идее революции; посетив Америку, дал верную оценку её научно-техническому прогрессу и духовному регрессу.

Что способствовало становлению личности Маяковского? Конечно, сильный дух был заложен в детстве, благодаря атмосфере любви в семье. Рос он среди представителей разных этносов, гордых кавказцев, стал интернационалистом. Но окончательно духовно возмужал в гимназические годы, благодаря общению с революционно настроенными студентами и участию в подпольной работе. В гимназические годы бедствовал, не имел средств досыта поесть, был свидетелем социальной несправедливости, видел, как представители привилегированных слоёв купались в роскоши.

Трудно дать однозначную оценку самоубийству. Конечно, психологически можно понять названных суицидентов: все они были впечатлительными натурами. Что отличает художника от других людей? Он ярко и бурно воспринимает явления, события. По сравнению с обыкновенным человеком во много раз больше тратит нервной энергии, поэтому нуждается в ежедневном восполнении жизненной энергии за счёт получения положительных эмоций. Но если вовремя не восстанавливается затраченная энергия, то в стрессовых ситуациях происходит нервное истощение, садится «внутренний аккумулятор» и человек выходит из душевного равновесия, начинает себя вести неадекватно, в жизни принимает неверные решения, и дальнейшая судьба оказывается непредсказуемой.

Маяковский никогда не жалел своей энергии, днём и ночью работал в «Окнах РОСТа», выпускал сатирические плакаты, подписывал колкими стихами, направленными против врагов революции, препятствующим становлению новой жизни. Чтобы не спать долго, под голову клал полено. Был настоящим трибуном революции. Регулярно выступал на дискуссиях в Политехническом музее, сходу парируя выпады недоброжелателей. Графоманам часто перепадало от него, но они не прощали обид. Завистники подкидывали записки: все талантливые поэты в твоём возрасте уже стрелялись, не пора ли и тебе? Тем самым 


\section{Филология: научные исследования 4 (08) • 2012}

они в его подсознании программировали конкретные действия. И началась травля поэта. Даже друг Борис Пастернак (которого он высоко ценил) вплёл свой голос в хор шельмующих. Потом одумался, пришёл извиняться, но Маяковский, как об этом свидетельствует Лев Кассиль ${ }^{1}$, не принял извинения, руки не подал, отвернувшись от него, сказал:

- Пусть он уйдет. Так ничего и не понял. Думает, что это как пуговица: сегодня оторвал - завтра пришить можно обратно... От меня людей отрывают с мясом!.. Пусть он уйдёт.

Очень болезненно воспринял Маяковский организованный бойкот выставки «20 лет работы», посвящённой творчеству и пропагандистской деятельности. Это был своеобразный отчёт перед власть имущими и компетентными людьми: поэт-трибун ждал заслуженного признания. Он нуждался в поддержке, в получении нового импульса для дальнейшей яростной работы. Но на открытие выставки Владимира Маяковского не пришёл ни один из членов Правительства, хотя каждому из них, в том числе, Сталину, Молотову, Ворошилову, Кагановичу было вручено приглашение. Не пришли и писатели: друзья из Рефа (Революционный фронт искусств) обиделись за то, что покинул их (притом даже не посоветовавшись), а в РАППе (Российской ассоциации пролетарских писателей), куда он перешёл (вернее сказать, «переметнулся»), не признавали за своего, намекая на дворянское происхождение. Завистники обзывали «попутчиком в революции». Какой же это попутчик, если за пропагандистскую деятельность в уже 15 лет несколько раз подвергался аресту, а в 16 лет был заключён в одиночную камеру Бутырской тюрьмы?! И всю свою жизнь посвятил делу служения революции.

Кроме всего прочего, провалилась постановка драмы «Баня». Виной тому было давление прессы: ещё за неделю до постановки рапповец Ермилов написал пасквиль в «Правде», затем началось моральное гонение. В газетах писали: Маяковский лет на пять опоздал — в СССР с бюрократизмом давно покончено, Маяковский очерняет Советское государство. Поползновения были даже в адрес превосходной комедии «Клоп». Можно сказать, что Сталину и сталинистам талантливый поэт пришёлся не ко двору. Если бы он не застрелился, то по ложному обвинению мог бы оказаться в ГУЛАГЕ или быть застреленным.

Конечно, Маяковского угнетала неустроенность личной жизни, отсутствие своего гнёздышка и детей, которых он очень любил. Но проблема не решалась ввиду отсутствия достойной пары. Любимые женщины

\footnotetext{
${ }^{1}$ Михайлов А.А. Маяковский. М.: Молодая гвардия, 1988. C. 523-524.
}

оказывались с невысоким уровнем духовности, боялись не оправдать его надежду и не выполнить функцию спутницы жизни знаменитого поэта и неугомонного бойца. Первой женщиной, предавшей любовь Маяковского, была какая-то Мария. О сильных переживаниях поэта мы знаем из поэмы «Облако в штанах». Он был унижен ей до крайности, сравнивает себя с собакой, которая лижет бьющую руку. Его понять можно. Но, думаю, Мария была права: женское сердце почуяло и сделало верный вывод: «не в свои сани - не садись». А, может, у неё было другое видение мужа. В любом случае Маяковский из-за своей любовной страсти не разглядел в ней изъянов. Уверен, с Марией у него получилась бы заурядная семья, стать другом она бы не смогла, и личного счастья с ней бы не познал. Семью не создают, выпрашивая любовь. Трещина, возникшая в отношениях между ними, в дальнейшем увеличивалась бы и помешала им слиться воедино.

Трагедия поэта определялась ещё тем, что он жил в условиях разрыва сложных социальных связей - атрибутов культуры. Согласно проникающим в Россию западным ценностям свободу стали понимать как абсолютную независимость. Не в высокой цене была супружеская верность. Идеология индивидуализма распространялась шире и шире, считалось допустимым переманивание чужой жены. Люди, как и на Западе, стали отчуждаться друг от друга. Поэтому Маяковский постепенно сильнее и сильнее стал ощущать своё одиночество, душевный дискомфорт. Много раз говорил про смерть и писал: «Скоро вот и я умру и буду нем».

Жаль, что россиянин (и тогда, и сейчас) не может понять, что этнокультура способствует образованию целостного человека с гармоничным внутренним миром, что вне этнокультуры даже такому духовно сильному человеку жилось нелегко. Открытый человек, окружённый к тому же посредственными людьми, и категорично бросающий вызов судьбе, не имея рядом источника душевной энергии, выходит из равновесия и рано или поздно начинает «ходить на цыпочках», теряет под собой почву. Гуляя ночью по Москве, встретился с А.Н. Серебровым и жаловался, что душевные силы его на исходе, признавался: «У меня нет друзей. А иногда такая тоска — хоть женись! Вот иду в РАПП!.. Посмотрим, кто кого! Смешно быть попутчиком, когда чувствуешь себя революцией... Легко сказать - плюнуть... Я уже не плюю, а харкаю кровью... Не помогает... лезут... И мне кажется, я никому больше не нужен...»².

Маяковский жил по принципу «всё или ничего» и не мог взять в жёны первую попавшуюся женщину.

\footnotetext{
2 Там же. С. 514.
} 


\section{Авторская маска}

Страстно полюбил русскую парижанку Татьяну Яковлеву, надеялся, что приедет к нему в Москву. Уезжая из Парижа, цветочнику оставил деньги, чтобы он каждую неделю приносил ей букет роз с любовной запиской. Но Татьяну, избалованную парижским комфортом, не устраивало его жильё, делала нарекания, почему, мол, революция, которой занимаешься, не может обеспечить тебя сносными условиями? Для чего нужна такая революция? Ответил ей стихотворением «Письмо Татьяне Яковлевой», мол, ревную уже не за себя, а за Советскую Россию. В конце подытожит: «Любовная лодка разбилась о быт». Может, удалось бы осуществить мечту, как он писал, «Я всё равно тебя когда-нибудь возьму - одну или вдвоём с Парижем». Но его не пустили за границу, боясь, что трибун революции из-за страстной любви может остаться во Франции. Это было прямым оскорблением патриота Советской России. Невеста вскоре вышла замуж за какого-то виконта, счастлива с ним не была, развелась. Но поэту-глыбе, автору самых лиричных и гражданственных стихов, поэту «с большими и неуклюжими руками» и нежной душой от этого легче не стало. Его пылкая любовь обернулась душевной опустошенностью.

Предсмертную записку Маяковский написал за два дня до трагической развязки. Не спешил уходить, не хотел умирать, цеплялся за соломинку, но никто не понял его состояние (или не хотел понимать) и не протянул руку, чтобы вытащить из депрессии. Во время депрессии человек смотрит на мир как сквозь щёлочку, зацикливается на своей болячке, и мимо его внимания уходят многие (более важные) ценности. Так, у Владимира Маяковского остались близкие родственники и миллионы поклонников таланта, особенно среди советской молодёжи. В том числе, у него остались мать Александра Алексеевна, сестры Ольга и Людмила, на день рождения которой в голодном году две морковинки принес «за зелёный хвостик».

Моё убеждение, что Маяковский — жертва цивилизации. Во-первых, вслед за другими западниками не понял, что глубокие натуры есть не только среди горожан, не только среди интеллигенции. Ему, должно быть, и в голову не приходило искать себе жену из среды традиционных крестьян, поскольку, по мнению западников (революционеров), деревенские жители - отсталые люди. Наверное, и не подумал: а в чём отсталые? По человеческим качествам (трудолюбию, милосердию, восторженно-поэтическому восприятию мира, жизненной энергии, терпеливости, жизненной мудрости...) земледельцы не отстают от прочих социальных групп, а подчас и опережают.

Во-вторых, Маяковский был вовлечён в водоворот революционного динамизма, разрушающего нравствен- ные устои, не оставляющего времени философски осмыслить себя, свою судьбу, правильность принятых решений. Революция - чисто западное явление, в неё многое привносится волюнтаристски от субъекта революции. Почему Л.Н. Толстой выступал против революционных методов переустройства общественной жизни? Потому что революция — палка о двух концах — бьёт и по самому революционеру. Главный девиз революции «Долой!» приводит к эффекту бумеранга. Революционер забывает, что «душа завоёвывается не оружием, а любовью и великодушием» (Б. Спиноза). Революция подобна джину, которого можно выпускать из бутылки лишь в том случае, если знаешь, как им управлять. Но откуда быть разумному рулевому в условиях утраты этнокультуры? Великая Французская революция тоже вначале устанавливала социальную справедливость и для уничтожения врагов изобрела гильотину, а потом руководители революции под неё пустили своих соратников (Марат, Робеспьер и др.). Под подобную «гильотину» попал и Маяковский.

Маяковский знал себе цену: «Мне бы памятник при жизни полагается по чину. Заложил бы динамиту — нука, дрызнь! Ненавижу всяческую мертвечину! обожаю всяческую жизнь!» В день Юбилея А.С. Пушкина разговаривал на равных с его памятником, установленном на Тверским бульваре г. Москвы: «После смерти нам стоять почти что рядом: Вы на Пе., а я на эМ. Кто меж нами? с кем велите знаться?! Чересчур страна моя поэтами нища». Благодарные потомки воздали должное Маяковскому: памятник воздвигли на соседней с Тверским бульваром площади.

Поэт был прав, в окружении его мало было достойных товарищей по цеху. Но, возможно, не стоило рвать и метать и пытаться кавалерийским наскоком построить новую жизнь? Может надо было уживаться с посредственными поэтами, идти на компромисс в непринципиальных вопросах, терпеть дармоедов и не раздавать всем и вся нелестные эпитеты? Мир взаимосвязан - на человека влияет деятельность, которой он занят, влияют люди, с которыми он общается. Если сравнить работу воспитателя детского садика, общающегося с чистыми незамутнёнными душами, и работу воспитателя-командира с заключёнными в колонии, психика которых подорвана, то можно представить разницу в последствиях от контактов с разными категориями людей. Кроме того, необходимо учесть последействия поступка: доброе слово, доброе дело меняет человека иначе, чем брань. На дискуссиях в Политехническом музее ему приходилось состязаться с оппонентом в споре, кто из них умнее. Поэт-скандалист (как он себя называл) благодаря своему остроумию, всегда выходил победителем. Но не временной ли эта победа была? 


\section{Филология: научные исследования 4 (08) • 2012}

Хочу сказать, что выпады Маяковского в адрес «дряни» - не проходили бесследно, способствовали эрозии собственной поэтической души. Уверен, в полемике на эту тему победителя быть не может. Истинно умный человек (мудрец, диалектик) никогда не доказывает другому, что тот глуп. Если даже докажет, тот не станет умнее. В таком случае для чего затеяно состязание? Душевное состояние человека улучшается не тогда, когда он занимается злом, а тогда, когда занимается добродетелью. Маяковский в адрес Есенина писал: «Надо чтоб поэт и в жизни был мастак. Мы крепки, как спирт в полтавском штофе». Действительно, так. Но советовать оказывается легче, чем претворить идею в жизнь, и крепкий спирт, оказывается, выдыхается. Ему, надо полагать, некогда было заниматься познанием самого себя.

Талантливый голландский художник Ван Гог ощутил себя лишним человеком оттого, что его творчество не востребовано социумом. Он был высокого мнения о своём творчестве и обиделся, что оно не пользовалось спросом, бывало, расплачивался в кафе, оставив за обед картину. Его обиду можно понять: вскоре после его смерти картины были признаны шедеврами - оценивали и скупали за миллионы. Ему, как и Маяковскому, может, следовало терпимее относиться к бесталанным людям (неспособным оценить его талант), и уменьшить уровень своих притязаний. Но он как импрессионист писал картины чистыми красками, не смешивая, и к жизни тоже отнёсся категорично, не признавая оттенков. Мог бы быть более терпимым - примеры есть среди философов.

Между прочим, Бенедикт (Барух) Спиноза, соотечественник Ван Гога, в Испании был гоним за еврейскую национальность, а в Голландии представители еврейской общины его преследовали и пытались убить за пантеистическое мировоззрение. Он вынужден был скрываться и от соплеменников, и от властей, жить на окраине города, работать шлифовщиком линз, чтобы иметь возможность заниматься любимой философией и изливать на бумаге свои идеи. Необходимо притом иметь в виду, что Спиноза печататься под своей фамилией не мог, многие труды увидели свет только после его смерти. Жил в бедности, но, по-своему, был счастлив - счастлив от ощущения и осознания своей духовной свободы, от возможности игнорировать давление социума и возможности заниматься творческим трудом и быть самим собой. У него не было мысли рассчитаться со своей жизнью, напротив, был оптимистом и спешил найти ответ на многие политические, богословские и философские вопросы. Биография Спинозы, как и философские труды, достойны изучения - они побуждают к глубокому размышлению. Он, хотя прожил недолго, сделал огромный вклад в разработку философских ка- тегорий и много раз демонстрировал диалектическое мышление, в том числе, определяя категорию «свобода» как познанную необходимость.

Представляет интерес такой факт: узники концлагеря и тюрьмы не спешат добровольно уходить из жизни. Почему? Не оттого ли, что этим они никому ничего доказать не смогут? И нельзя ли рассматривать самоубийство проявлением эгоизма? У Ван Гога был брат, который, не выдержав разлуки, скончался через четыре месяца после самоубийства любимого брата. Подумал ли о нём самоубийца или как обыкновенный эгоцентрист руководствовался лишь собственным чувством обиды, решив, что он в этой жизни абсолютно свободен и никому ничем не обязан?

Для западника действие (динамическая жизнь) является самоцелью: если результат действия окажется негативным, он будет искать виновника вне себя. Почвенник в отличие от него, прежде чем сделать новый шаг, вначале оглянется, посмотрит вправо, влево, подумает о последствиях. Он всегда помнит о взаимосвязанности мира, размышляет о причинно-следственных связях.

Можно ли было художникам (В.В. Маяковскому и Ван Гогу, о жизни и деятельности которых я размышляю) продолжать жить в условиях непризнания таланта? Вопрос очень непростой, чтобы ответить на него, необходимо осуществить анализ. По мнению Н.А. Бердяева, не стоит жить недостойной жизнью. В таком же духе рассуждает и М. Горький. В рассказе «Однажды осенью» семнадцатилетний безработный парень от первого лица описывает проститутку, избитую её «кредитным» (альфонсом). Оказавшись в чужом городе без денег, вынужден был провести ночь с незнакомой девушкой под лодкой на берегу Волги. Жалеет падшую девушку, покорившую его своим милосердием. Он крайне удивился, что даже в униженном состоянии она проявляла заботу о совершенно чужом человеке, утешала его, вселяла надежду в перемену жизни в лучшую сторону, предлагала помощь в поиске работы. Видимо, она выросла в деревне, в условиях традиционной культуры и вобрала в себя народную доброту, душевность. Но в силу обстоятельств оказалась в публичном доме. Автор рассказа от первого лица говорит, что по душевным качествам эта падшая девушка стоит выше всех женщин, с которыми когда-либо сводила судьба. Впоследствии он стал разыскивать её, чтобы принять участие в её судьбе, но не нашёл. Рассказ заканчивается словами: может она умерла? если так, то как бы это было для неё хорошо. По мнению, Горького смерть для девушки лучший исход в такой невыносимой жизни.

Маяковский осуждал Сергея Есенина за самоубийство: «В нашей жизни умереть нетрудно, сделать жизнь - значительно трудней». И в предсмертной записке 


\section{Авторская маска}

писал: «другим не советую». Тем не менее, покончил собой, мол, «у меня выходов нет». Почему такой умный человек решил, что выходов нет? Значит, можно делать вывод, что им управлял всё-таки не разум, а эмоции? Да, если человек ещё не обрёл нелинейного мышления, то его сознанием можно манипулировать, можно внушить мысль о его несостоятельности (в качестве мужчины, добытчика, специалиста, поэта, человека...). А человек, обретший нелинейное мышление, управляет и своим рассудком, и чувствами, и ощущениями, и инстинктами. Таковыми являются мудрые люди, аксакалы, восточные монахи. Таковой была и моя мама-крестьянка. Человек, достигший уровня разума, внутренне свободен, внутри самого себя находит духовную силу и поддерживает свою психику, может даже поменять «Я-концепцию».

А где могли бы черпать источник жизненной энергии кандидаты в самоубийцы? Могли бы получить положительные эмоции от микросоциума, от близкого человека, который находится рядом. Маяковского могла бы спасти женщина, способная жертвовать собой. Таковой могла быть актриса Вероника Полонская, с которой его познакомили Осип Брик и его супруга Лиля. Подружился с ней, стал регулярно встречаться, искал в ней утешение-поддержку.

Полонская заблаговременно была извещена о его душевном кризисе - за день до самоубийства он предупредил её о возможном трагическом конце, просил не отходить от него, бросить театр, не ходить на репетицию, остаться у него насовсем, тем самым доказав ему свою преданность и дать искорку для заглохшего внутреннего мотора. Но будучи эмансипированной женщиной прозападного типа, не хотела жертвовать только что полученной главной ролью в новом спектакле и ушла от него на назначенную репетицию. Он застрелился не оттого, что она ушла, а оттого, что она продемонстрировала свою духовную скудость, он почувствовал, что в её душе маловато тепла, необходимого согреть его озябшую гигантскую душу. Соответственно понял, что она не способна дать ему того, что он ожидает от своей половинки. Понял, что его ожидает жизнь, заполненная мученической ревностью. Разве в таком случае может иметь место возвышающая любовь? Как нормальной эмансипированной женщине ей любовь нужна была только для удовольствия - как известно, любовь индивидуалистки не сопрягается с жертвами и страданиями. Её артистическая душа, поражённая ржой честолюбия и вирусом славы, не могла посвятить себя ограничению пределами клетушки Маяковского (как это ей казалось). Она далека от философской рефлексии и мысли о своём женском предназначении. Вообще, какая богемная женщина (артистка, поэтесса...) может поддерживать домашний очаг? В любом случае налицо издержки прозападной цивилизации, способствующей отчуждению людей и мешающей полностью слиться двум душам в единое целое.

Маяковский всю жизнь искал натуру, подобную себе, способную любить без холодного расчёта полностью раствориться в объекте любви. Сам он любил по-настоящему - ничего не жалея для любимой. Но, не встретив подобную под стать себе, почувствовал себя одиноким, полностью разочаровался. И неудивительно, что, в конце концов, «жизненный стержень» сломался. Полонская, уходя, взяла с него слово, что он не застрелится, но, как только дверь за ней затворилась, потянулся за револьвером. В коридоре она услышала, как раздался выстрел.

Какая причина привела к самоубийству Эрнеста Хемингуэя, всемирно известного американского писателя, Лауреата Пулитцеровской и Нобелевской премий? По внешним показателям у него всё обстояло благополучно. Отличался сильным духом, в своих произведениях отстаивал гуманистические ценности. Был любим женщинами. Казалось бы, с точки зрения представителя западной цивилизации, налицо все атрибуты состоявшейся личности.

Поводом для самоубийства послужила потеря способности творить: по воле судьбы он оказался в руках врачей-психиатров, те усердно лечили и выжгли в его головном мозге центры творчества. Их трудно винить, поскольку делали то, чему их учили. Но Хемингуэй выразил свой протест врачам в форме суицида. Да, для писателя лишение возможности творить - это трагедия, но не повод для завершения жизненного пути. Философ-стоик или традиционный крестьянин на его месте постарался бы найти другой смысл жизни, нашёл бы способ принести пользу, если не всему человечеству, то тому, кто находится рядом. В повести «Старик и море» Хемингуэй проповедует идею сохранения человеческого достоинства и мужества перед судьбой, несущей страдания. Почему в собственной жизни покинуло мужество? Налицо разрыв между словом и убеждением!

У Хемингуэя оказался порок, который есть у типичного западника: жизнь была посвящена самоутверждению, обретению славы. Им овладели амбиции, считал себя уникальным. Очевидно, он был далёк от философской рефлексии: всю жизнь старался удивлять мир, поражать поклонников своим творчеством. Слава подобна наркотику - насыщения никогда не наступает - чем дальше, тем больше требуется. Всё то, чем он занимался всю жизнь, есть лишь средство, есть театр, где разыгрывается его честолюбие. То есть мы имеем перед собой яркого индивидуалиста. Это есть 


\section{Филология: научные исследования 4 (08) • 2012}

нарциссизм - проявление деформации личности. Трагический конец Хемингуэя был предопределён именно нарциссизмом. При этом вина за гибель выдающегося писателя ложится на цивилизацию. Западный социум не способствует становлению целостного человека, не помогает самоутверждению в подростковом возрасте через созидание материальных и духовных ценностей; с самых ранних лет нацеливает не на самосовершенствование человека, не на принесение пользы людям, а на разного рода победы над себе подобными. Западник стремится попасть в книгу Гиннеса, удивить людей какими-то способностями, талантом. Такая неверная установка ставит преграду на пути индивида к обретению разума, и сознание его ограничивается уровнем интеллекта.

При знакомстве с биографией Хемингуэя обнаруживается, что к женщине относился потребительски, думал прежде о себе, а не о счастье семьи. Был женат четыре раза. Жёны рожали ему сыновей, но, похоже, об их судьбе он не думал. Интересная позиция! Мир ему обязан чем-то, а он никому и ничем не обязан? В таком случае он не усвоил диалектический закон о взаимосвязанности мира. И естественно, судьба его покарала: в конце жизни раскаивался в том, что развёлся с первой женой Хедли Ричардсон, развод называл «величайшим грехом» своей жизни. Но пленился прекрасной Полин Пфейфер (продемонстрировав тем самым свой инфантилизм). Четвёртая жена Мэри Флэш была на девять лет моложе, к тому же красивая, терпеливая, относилась к мужу с почтением и благоговением. Но Хемингуэй её, как и всех других женщин, держал на расстоянии, всю жизнь занимался флиртом, душу и сердце никому не доверял, не пытался создать единое целое из двух половинок. Таков типичный эгоцентрист. Конец его жизни тоже, можно сказать, типичный.

Моя мать считала, что необходимо продолжать жить и в невыносимых условиях. Она понимала жизнь как решение бесконечных проблем, ни в какой ситуации не паниковала, искала выход из любого трудного положения. Осуждала самоубийц и говорила: «У меня было тысячи причин покончить собой, но терпела». Действительно, традиционный крестьянин презирает физические страдания, игнорирует давление внешних сил, в стрессовых ситуациях одёргивает паникёров; придерживается одинаковой жизненной позиции с древнегреческим философом Эпиктетом, который в любых условиях - богатства или нищеты, власти или рабства - сохранял внутреннюю независимость и духовную свободу. Он все вещи и дела разделял на зависящие от него и не зависящие: в первых мужественно исполняет свой долг, вторые - игнорирует.
Когда я в детстве жаловался на холод, мне взрослые крестьяне выговаривали: «Разве живой человек может мёрзнуть?» Предполагалось, предприми что-то: шевелись, работай, бегай, прыгай... Также не признавали жалобы на усталость. По их мнению, мудрость в том, чтобы презирать страдания, преодолеть трудности, преодолеть самого себя.

Можно предположить, что Ван Гог, Эрнест Хемингуэй и Владимир Маяковский (наряду со многими другими деятелями искусства) стали также жертвами «медных труб». Их беда заключалась в том, что они были лишены философской рефлексии. Каким бы свободолюбивым ни казался профессиональный художник (писатель, артист), если он не свободен от славы, искусство служит ему, как правило, средством самоутверждения, средством возвыситься над себе подобными. В отличие от профессионального художника как типичного западника, у традиционного крестьянина имеется большое преимущество в том смысле, что он творит для удовольствия, а не ради славы. Традиционный крестьянин имеет восторженно-поэтическое восприятие мира. Удивительно: представитель серой массы создаёт фольклор, народную мудрость и поэтические произведения, с которыми не может сравниться ни один философ, ни один поэт. Он всю жизнь творит: работая строителем, украшая своё жильё изнутри и снаружи, творит в огороде, поле - в работе земледельца прошлогоднего повтора (стереотипа) не бывает, каждый раз приходится соображать, экспериментировать, рисковать. Но созидая новое, крестьянин никому не доказывает своё превосходство над другими людьми, по привычке всё делает как лучше, при этом всю жизнь ощущает свою недостаточность, своё несовершенство. Подобными, подверженными философской рефлексии, являются лишь немногие представители творческой интеллигенции.

Мы, дорогой читатель, в данном случае встречаемся с двумя разными подходами к человеческой жизни: одна сторона осуждает живущих недостойной жизнью, другая призывает не спешить отказываться от жизни ни при каких условиях. Вторая сторона скорее выражает мировоззрение традиционных крестьян, являющихся субъектами своей судьбы, умеющих довольствоваться малым, способных идеализировать жизнь и окружающих людей, считающих, что людей и жизнь надо принимать такими, какие они есть. Кто прав?

Размышляя о самоубийцах, можно задаться вопросом: почему среди евреев нет проблемы с суицидом, хотя они тоже живут в несовершенном обществе? Особого секрета нет: их «внутренний аккумулятор» постоянно подзаряжается в «тихой гавани» (семье), благодаря сохранившейся этнокультуре и душевности отношений, 


\section{Авторская маска}

благодаря культу ребёнка и женщины. Жизненная энергия евреев поддерживается также и национальной общиной. Общинные отношения, с одной стороны, дают ощущение защищённости, с другой - приучают соизмерять свои желания с волей микросоциума. То есть общинные отношения строятся с учётом общественной природы человека.

Я не смею осуждать самоубийц вслух. Считаю, что они явились жертвами нашей несовершенной цивилизации, которая игнорирует общественную природу человека и разрушила этнокультуру как систему социальных связей, гарантирующих психологическую и социальную защищённость каждого индивида. В западной цивилизации, ориентированной на индивидуальное выживание, считается, что спасение утопающих дело рук самих утопающих. Но, думаю, окажись суициденты в дружбе с философом-диалектиком, тот бы убедил, что к жизни необходимо относиться по-философски - философия не оправдывает суицидальное поведение.

Но с самоубийством древнегреческого философа Сократа, видимо, всё-таки придётся смириться. Правда, смерть Сократа принципиально отличается тем, что он покончил собой благодаря сильному духу (в отличие от приведённых примеров, когда суицид был совершён по причине ослабления жизненного духа). Он, как известно, не послушался друзей и не сбежал за границу - подчинился решению суда и принял яд. На суде выступил с обвинительной речью в адрес судей и власть имущих, доказывая несостоятельность их миропонимания, предрекал их поражение. Действительно, он продемонстрировал свою диалектичность и своей смертью победил врагов - возмездие в скором времени пришло. Пример с Сократом говорит о том, что к оценке судьбы каждого индивида, каждого конкретного случая необходимо подходить без шаблона.

\section{Список литературы:}

1. Михайлов А.А. Маяковский. М.: Молодая гвардия, 1988.

\section{References (transliteration):}

1. Mikhaylov A.A. Mayakovskiy. M.: Molodaya gvardiya, 1988. 